FERRAREZI, RS; VAN IERSEL, MW; TESTEZLAF, R. 2016. Plant growth response of subirrigated salvia 'Vista Red' to increasing water levels at two substrates. Horticultura Brasileira 34: 202-209. DOI - http://dx.doi.org/10.1590/S0102-053620160000200009

\title{
Plant growth response of subirrigated salvia 'Vista Red' to increasing water levels at two substrates
}

\author{
Rhuanito S Ferrarezi ${ }^{1}$; Marc W van Iersel²; Roberto Testezlaf ${ }^{3}$ \\ ${ }^{1}$ University of the Virgin Islands, Kingshill-VI, United States; rhuanito@terra.com.br; ${ }^{2}$ University of Georgia, Athens-GA, United States; \\ mvanier@uga.edu; ${ }^{3}$ UNICAMP, Campinas-SP, Brazil; bob@feagri.unicamp.br
}

\begin{abstract}
Subirrigation applies water and nutrients to the bottom of pots without wetting leaves, improving water use and reducing disease spread compared to overhead irrigation systems. However, water levels applied within the benches are often higher than required to promote capillary action, applying more water than needed and wasting pumping energy. The present study was conducted to evaluate the effect of different water levels on plant growth of subirrigated salvia (Salvia splendens) 'Vista Red' in two substrates. Five water levels $(0.75,1.5,3.0,4.5$, and $6.0 \mathrm{~cm})$ and two substrates \{pine bark: sphagnum peat moss and peat: perlite (both $75 \%: 25 \% \mathrm{v} / \mathrm{v}$ ) $\}$ were tested, with four replications. Substrate moisture was monitored by capacitance-type sensors connected to a multiplexer and data logger. Volumetric water content (VWC) was higher in peat: perlite ( 0.34 to $\left.0.75 \mathrm{~m}^{3} / \mathrm{m}^{3}\right)$ than pine bark: sphagnum peat moss $\left(0.21\right.$ to $0.60 \mathrm{~m}^{3} /$ $\mathrm{m}^{3}$ ) at all water levels. Higher water levels increased VWC in both substrates. The leaf chlorophyll index was $4 \%$ lower at the $6.0 \mathrm{~cm}$ compared to the other treatments in peat: perlite $(p<0.0001)$. Stomatal conductance decreased overtime; but increased with the increase in water levels in peat: perlite $(p<0.0001)$. Different water levels had no effect on leaf area, net photosynthesis, number of branches and leaves, and shoot dry weight ( $\mathrm{p}>0.05)$, an indication that the different water levels do not affect the plant growth. However, shoot plant height increased $13 \%$ in pine bark: sphagnum peat moss $(p=0.0096)$ and $17 \%$ in peat: perlite $(\mathrm{p}=0.0335)$ as water levels increased. Water levels of $1.5 \mathrm{~cm}$ and higher can be recommended for pine bark: sphagnum peat moss or peat: perlite in subirrigation, applying water according to plant needs, optimizing plant growth and reducing the nutrient solution pumping costs compared to systems that apply higher water levels.
\end{abstract}

Keywords: Salvia splendens, subirrigation, automation, capacitance sensors, irrigation, water management.

\section{RESUMO}

Crescimento de sálvia 'Vista Red' em subirrigação com diferentes alturas de lâmina de água em dois substratos

Na subirrigação água e nutrientes são aplicados na parte inferior dos recipientes de cultivo, otimizando o uso da água e reduzindo a propagação de doenças quando comparada com sistemas de irrigação por aspersão. No entanto, as lâminas aplicadas dentro das mesas são geralmente mais elevadas que o necessário, com aplicação inadequada de água e desperdício de energia para bombeamento. $\mathrm{O}$ presente estudo foi realizado para avaliar o efeito de diferentes alturas de lâmina de água no crescimento de plantas subirrigadas de sálvia (Salvia splendens) 'Vista Red' em dois substratos. Foram testadas cinco alturas de água $(0,75 ; 1,5 ; 3,0 ; 4,5$ e $6,0 \mathrm{~cm})$ e dois substratos \{casca de pinheiro: esfagno e turfa: perlita (ambos na proporção $75 \%: 25 \% \mathrm{v} / \mathrm{v})\}$, com quatro repetições. A umidade do substrato foi monitorada por sensores capacitivos conectados a um multiplexador e sistema automático de aquisição de dados. O conteúdo volumétrico de água (CVA) foi maior na casca de pinheiro: esfagno $(0,34$ a $\left.0,75 \mathrm{~m}^{3} / \mathrm{m}^{3}\right)$ do que na turfa: perlita $\left(0,21\right.$ a $\left.0,6 \mathrm{~m}^{3} / \mathrm{m}^{3}\right)$ em todas as lâminas testadas. Alturas de água mais elevadas proporcionaram maior CVA em ambos os substratos. $\mathrm{O}$ indice de clorofila no tecido foliar foi $4 \%$ menor para o tratamento $6,0 \mathrm{~cm}$ em comparação com os outros tratamentos na turfa: perlita $(\mathrm{p}<0,0001)$. A condutância estomática diminuiu ao longo do tempo, porém aumentou com o incremento das alturas de lâmina de água na turfa: perlita $(\mathrm{p}<0,0001)$. Diferentes alturas de lâmina de água não causaram efeito na área foliar, fotossíntese líquida, número de ramos e de folhas e massa seca da parte aérea $(\mathrm{p}>0,05)$, um indicativo de que as diferentes alturas da lâmina de água não afetam o crescimento das plantas. No entanto, a altura da parte aérea aumentou em $13 \%$ para casca de pinheiro: esfagno $(p=0,0096)$ e $17 \%$ para turfa: perlita $(p=0,0335)$ com o aumento das lâminas. Alturas de lâmina de água maiores que $1,5 \mathrm{~cm}$ podem ser recomendadas para casca de pinheiro: esfagno ou turfa: perlita em subirrigação, com aplicação de água de acordo com as necessidades das plantas para otimização do crescimento vegetal e redução dos custos de bombeamento de solução quando comparado com sistemas de irrigação que aplicam lâminas de água mais elevadas.

Palavras-chave: Salvia splendens, subirrigação, automação, sensores capacitivos, irrigação, manejo hídrico.

(Recebido para publicação em 24 de março de 2015; 17 de janeiro de 2016) (Received on March 24, 2015; accepted on January 17, 2016)

$\mathrm{I}^{\mathrm{n}}$ subirrigation systems, water is applied to the bottom of pots, wetting the substrate by capillary action
(Ferrarezi et al., 2015a). This technology helps to increase plant uniformity and shorten the crop cycle in greenhouse production, with the option to recycle water and nutrients, avoiding runoff and reducing environmental contamination 
(Bilderback, 2002; Ribeiro et al., 2014).

Subirrigation control is commonly based on timers, without monitoring plant water requirements or substrate VWC required for optimal plant growth, often resulting in excessive water application and inefficient operation (Ferrarezi et al., 2015b). This type of control also uses water levels higher than needed to promote capillary action, wasting pumping energy and applying more water than required (Bilderback, 2002). Ferreira Filho et al. (2012) performed a study to assess the effect of different water levels and irrigation times on pine bark moisture in coneshaped containers, showing variability in VWC for different water levels inside subirrigation benches. Their approach used gravimetric water content determination, which is time-consuming for commercial purposes. A real-time technique to estimate the substrate moisture and apply water according to plant needs is imperative for commercial subirrigation application.

Capacitance sensors can be used to both monitor substrate water content and to control irrigation based on plant water use (Nemali \& van Iersel, 2006), thus applying water as needed and optimizing plant production in subirrigation systems (Ferrarezi et al., 2014). The capacitance/frequency domain technology determines VWC by measuring the dielectric constant of the soil/substrate and mathematically correlating the dielectric permittivity with moisture (Nemali \& van Iersel, 2006; Bogena et al., 2007; MirallesCrespo \& van Iersel, 2011). Several studies evaluated sensor-based irrigation using drip systems to improve water conservation in greenhouse and nursery crop production (Chappell et al., 2013; Lea-Cox et al. 2013; van Iersel et al., 2013). However, the application of this technology remains scarce in subirrigation production. Capacitance sensors were previously used in subirrigation by Ferrarezi et al. (2015b) in hibiscus (Hibiscus acetosella) 'Panama Red' and by Ferrarezi et al. (2014) in salvia 'Vista Red' using ebb-and-flow, and by Gent \& McAvoy (2011) in zonal geranium (Pelargonium $\times$ hortorum) ‘Allure Red Passion' using flood-floor. In these studies, the authors used only a fixed water level, provided by a specific time to allow an adequate substrate VWC. The establishment of water levels based on substrate- and crop-specific parameters is important for the success of subirrigation in commercial production systems. As subirrigation provides a variation in VWC after irrigations, the proper water level to apply the target VWC needs to be studied to avoid water stress caused by the deficit or excess of substrate moisture.

The aim of this work was to evaluate the effect of increasing water levels in plant growth of subirrigated salvia 'Vista Red' plants at two different substrates.

\section{MATERIAL AND METHODS}

\section{Location and environmental data}

- This study was performed in a glasscovered greenhouse in Athens, GA,

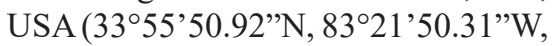
altitude $123 \mathrm{~m}$ ) during 34 days [from June 13, 2011 (DAT 0) to July 17, 2011 (DAT 34)]. Environmental conditions in the greenhouse were monitored using a temperature and relative humidity sensor (HMP50; Vaisala, Woburn, MA, USA) and a photosynthetic photon flux (PPF) sensor (QSO-Sun; Apogee Instruments, Logan, UT, USA) connected to a data logger (CR10X; Campbell Scientific, Logan, UT, USA). Readings were taken every 20 min and daily averages were recorded. The vapor pressure deficit (VPD) was calculated from the saturated and actual air vapor pressure, using the air temperature and relative humidity data. Averaged greenhouse environmental conditions over the experimental period were (mean \pm standard deviation): temperature $25.4 \pm 1.2^{\circ} \mathrm{C}$, relative humidity $77.7 \pm 4.2 \%$, VPD $0.56 \pm 0.12$ $\mathrm{kPa}$, and maximum PPF $1447 \pm 197$ $\mu \mathrm{mol} / \mathrm{m}^{2} / \mathrm{d}$.

Plant material - One hundredsixty salvia 'Vista Red' seedlings from a commercial nursery (Knox Nursery, Winter Garden, FL, USA) were individually transplanted to 10 $\mathrm{cm}$ square pots $(10 \mathrm{~cm}$ length $\times 10 \mathrm{~cm}$ width $\times 9 \mathrm{~cm}$ height). At the beginning of the experiment, shoot dry weight was $0.075 \mathrm{~g} / \mathrm{plant}$.

Treatments - We tested five water levels $(0.75,1.50,3.00,4.50$, and 6.00 $\mathrm{cm})$ in two commercial substrates [pine bark: sphagnum peat moss (75\%: $25 \%$ v/v, Fafard Nursery Mix) and peat: perlite ( $80 \%: 20 \% \mathrm{v} / \mathrm{v}$, Fafard 1P), both from Fafard, Agawam, MA, USA]. The water level treatments corresponded respectively to a ratio of $1 / 12,1 / 6,1 / 3$, $1 / 2$, and $2 / 3$ of the pot height, and were provided by applying a uniform water level in the benches $(6.0 \mathrm{~cm})$, and by placing the pots over plastic supports to achieve the desired water levels. Each experimental unit had four plants.

Subirrigation system - We used four ebb-and-flow benches with 115 cm length $\times 60 \mathrm{~cm}$ width $\times 15 \mathrm{~cm}$ height (Flood Tray; American Agritech, Chandler, AZ, USA) connected to individual 70-L tanks (Rubbermaid, Saratoga Springs, NY, USA) with a submersible pump inside (NK-2; Little Giant, Bluffton, IN, USA). Subirrigation was performed daily for 3 minutes using a timer (TimerMax Digislim; Stanley Black \& Decker Inc., New Britain, CT, USA). We used a nutrient solution with $100 \mathrm{mg} / \mathrm{L}$ of nitrogen (N) (15-5-15 Cal-Mag Special; Scotts Co., Marysville, OH, USA). Nutrient solution electrical conductivity (EC) and $\mathrm{pH}$ were measured at the beginning of the experiment and three times a week thereafter using an $\mathrm{EC} / \mathrm{pH}$ meter (Checkmate 90; Corning, NY, USA); solution $\mathrm{EC}$ and $\mathrm{pH}$ remained close to $0.59 \mathrm{dS} / \mathrm{m}$ and 6.0 throughout the experiment. Total nutrient solution used over this study was $112 \mathrm{~L}$ per replication (group of 40 plants). Each irrigation applied approximately $42 \mathrm{~L}$ per cycle, with drainage and recycling of unused nutrient solution.

Soil moisture sensors - Forty soil moisture sensors (EC-5; Decagon Devices, Pullman, WA, USA) connected to an AM16/32 multiplexer and a CR10X data logger (both from Campbell Scientific Inc., Logan, UT, USA) were used. The data logger excited the sensors with $2.5 \mathrm{~V}$ direct current (DC) and converted the voltage output readings to substrate VWC using a substrate- 
specific calibration equation [VWC= $1.886 \times$ (voltage output) -0.5624 ] developed following the manufacturer guidelines and the method of Nemali et al. (2007). Readings were taken every 30 minutes and averaged every 2 hours. We used a single sensor per pot and experimental unit, which was recommended by van Iersel et al. (2011) for small containers.

Measurements - The substrate VWC was measured over time using the soil moisture sensors. We performed weekly measurements on the third most fully expanded leaves of leaf chlorophyll index (SPAD-502; Minolta Camera, Osaka, Japan), leaf area (LI3100; Li-COR Biosciences, Lincoln, NE, USA), stomatal conductance, and net photosynthesis (CIRAS-2; PP Systems, Hitchin, England). At harvest (DAT 34), the number of branches, shoot height, total leaf area, total number of leaves, and total and partial dry weight

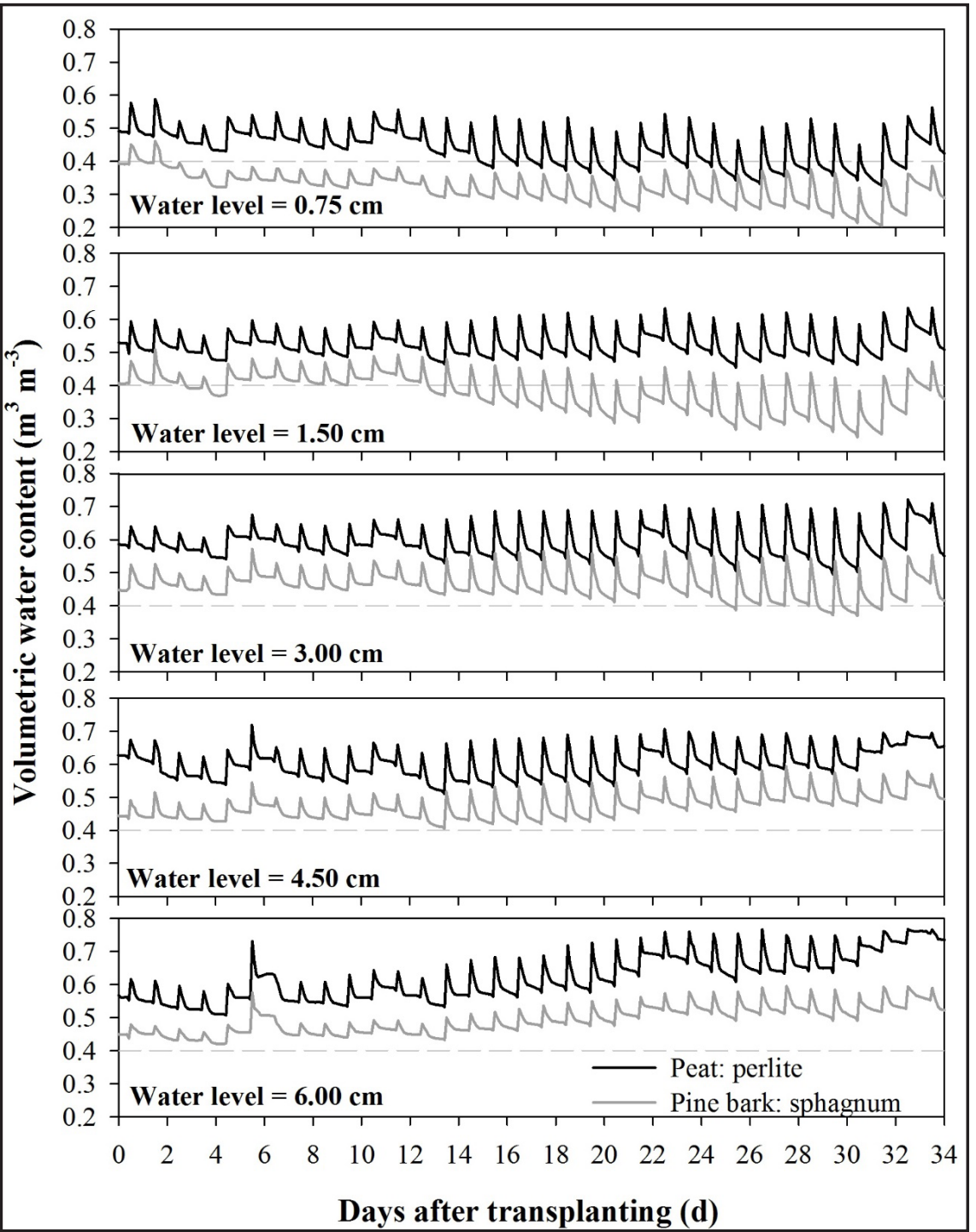

Figure 1. Volumetric water content (VWC) of salvia 'Vista Red' grown in pine bark: sphagnum peat moss and peat: perlite substrates. Gray line indicates the optimal moisture for most common potted plant production $\left(0.4 \mathrm{~m}^{3} / \mathrm{m}^{3}\right)$. The peaks in VWC indicate daily irrigations, followed by a gradual decrease caused due to evapotranspiration. Average of four replications \{conteúdo volumétrico de água (VWC) de sálvia 'Vista Red' cultivada em substratos de casca de pinus: esfagno e turfa: perlita. Linhas cinzas indicam a umidade ideal para a produção das plantas ornamentais mais comuns $\left(0,4 \mathrm{~m}^{3} / \mathrm{m}^{3}\right)$. Picos no VWC indicam irrigações diárias, seguidas por uma diminuição gradual causada devido à evapotranspiração. Média de quatro repetições\}. Athens, University of Georgia, 2011. (vegetative and reproductive parts separately) were measured. For dry weight, the shoots of four plants were cut off at the substrate level and dried in a forced-air drying oven at $70^{\circ} \mathrm{C}$ for 5 days before weighing.

Experimental design and statistical analysis - The experimental design was a randomized complete block design, with five water levels and two substrates tested in the same bench with four replications. Statistical analysis was performed using PROC REG in SAS (v. 9.2; SAS Institute, Cary, NC, USA). To determine treatment and time effects, a quadratic regression model, including an interaction term, was used: $\mathrm{Y}=\mathrm{a}_{0}+\left(\mathrm{a}_{1} \times \mathrm{DAT}\right)+\left(\mathrm{a}_{2} \times \mathrm{DAT}^{2}\right)+\left(\mathrm{a}_{3}\right.$ $\times$ water levels $)+\left(a_{4} \times\right.$ water levels $\left.^{2}\right)+$ $\left(a_{5} \times\right.$ DAT $\times$ water levels $)$, where $\mathrm{Y}=$ variables and $\mathrm{a}_{0}, \ldots, \mathrm{a}_{5}$ are regression coefficients. Significance levels $\leq 0.05$ were considered statistically significant. Non-significant components were eliminated using stepwise selection. Partial r-square, which indicates how much each variable uniquely contributed to $\mathrm{r}^{2}$, was obtained using scorr1 (seqtests) instruction.

\section{RESULTS AND DISCUSSION}

The system automatically monitored the substrate VWC throughout the experiment (Figure 1). The peaks in VWC values for all treatments indicate daily irrigations, followed by gradual decreases caused by evapotranspiration. As expected, higher water levels resulted in higher VWC in both substrates, which is in agreement with other studies using sensor-based subirrigation (Ferrarezi et al., 2014) and drip irrigation (Bayer et al., 2013), where higher thresholds to trigger irrigation resulted in higher VWC. Volumetric water content values were lower for pine bark: sphagnum peat moss than for peat: perlite substrate for all water levels, ranging from 0.21 to $0.60 \mathrm{~m}^{3} / \mathrm{m}^{3}$ in pine bark: sphagnum peat moss, and from 0.34 to $0.75 \mathrm{~m}^{3} /$ $\mathrm{m}^{3}$ in peat: perlite (Figure 1). The fast increase of VWC after an irrigation is common in subirrigated systems, not causing negative impacts on plant production (Gent \& McAvoy, 2011; 
Ferrarezi et al., 2014). However, this could be a drawback compared with drip irrigation systems, which can maintain the VWC close of the irrigation thresholds with a precision of $\approx 0.02 \mathrm{~m}^{3} /$ $\mathrm{m}^{3}$ (Nemali \& van Iersel, 2006; Bayer et al., 2013). The values found in peat: perlite substrate were much higher than the optimal substrate moisture of $0.4 \mathrm{~m}^{3} /$ $\mathrm{m}^{3}$ indicated for most common potted plant production (Kim et al., 2011). The VWC also decreased faster over time with the plant growth, because of the higher plant water use and transpiration (Figure 1). The water levels of 0.75 $\mathrm{cm}$ in pine bark: sphagnum peat moss and peat: perlite resulted in the lowest VWC over time (Figure 1). In pine bark: sphagnum peat moss, the water levels of 0.75 and $1.5 \mathrm{~cm}$ resulted in a VWC lower than the optimal value for potted plant production. In peat: perlite, just the level of $0.75 \mathrm{~cm}$ induced such response. These levels can be used to control plant growth, providing water restriction and resulting in compact plants (van Iersel $\&$ Nemali, 2004).

Leaf chlorophyll index increased over time from DAT 1 until DAT 22 in both substrates (Figure 2A and 2B, $\mathrm{p}<0.0001)$. Chlorophyll was solely the result of plant age in pine bark: sphagnum peat moss substrate (Figure $\left.2 \mathrm{~A}, \mathrm{r}^{2}=0.5847\right)$. In peat: perlite substrate (Figure $2 \mathrm{~B}, \mathrm{r}^{2}=0.7425$ ), the partial $r$-square of the interaction DAT $\times$ water level accounted only for 0.0169 of the variability (Table 1), indicating that most of the response was caused by plant age. After DAT 1, chlorophyll of plants grown in peat: perlite tended to decrease with increasing water levels. At harvest, the $6.0 \mathrm{~cm}$ treatment resulted in the lowest chlorophyll index in peat: perlite (Figure 2B).

As expected, leaf area increased weekly in both substrates (Figure 2C and $2 \mathrm{D}, \mathrm{p}<0.0001)$. All variation was caused by plant age for either pine bark: sphagnum peat moss and peat: perlite (Table $1, \mathrm{r}^{2}=0.7088$ for pine bark: sphagnum peat moss and $\mathrm{r}^{2}=$ 0.7974 for peat: perlite). The greatest leaf area was found in $1.5 \mathrm{~cm}$ treatment

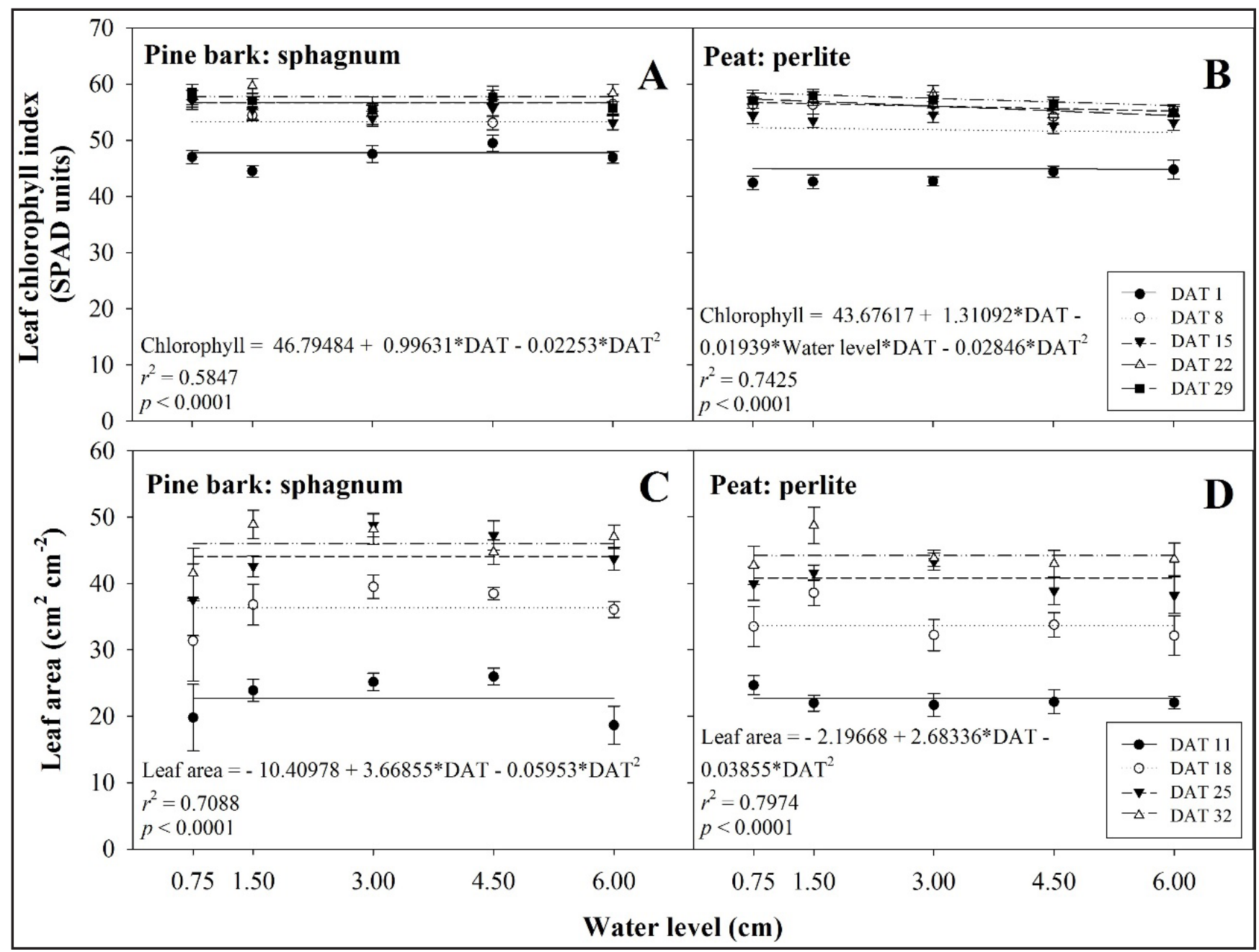

Figure 2. Leaf chlorophyll index (A-B) and leaf area (C-D) of third most fully expanded leaves of salvia 'Vista Red' grown in pine bark: sphagnum peat moss and peat: perlite substrates. Lines represent the regression equations. Each data point is the average (mean \pm standard error) of four plants per replication and four replications. DAT= days after transplanting \{́ndice de clorofila no tecido foliar (A-B) e área foliar (C-D) da terceira folha totalmente expandida de sálvia 'Vista Red' cultivada em substratos de casca de pinus: esfagno e turfa: perlita. Linhas representam as equações de regressão. Cada conjunto de dados é a média (média \pm erro padrão) de quatro plantas por repetição e quatro repetições. DAT= dias após o transplantio $\}$. Athens, University of Georgia, 2011. 


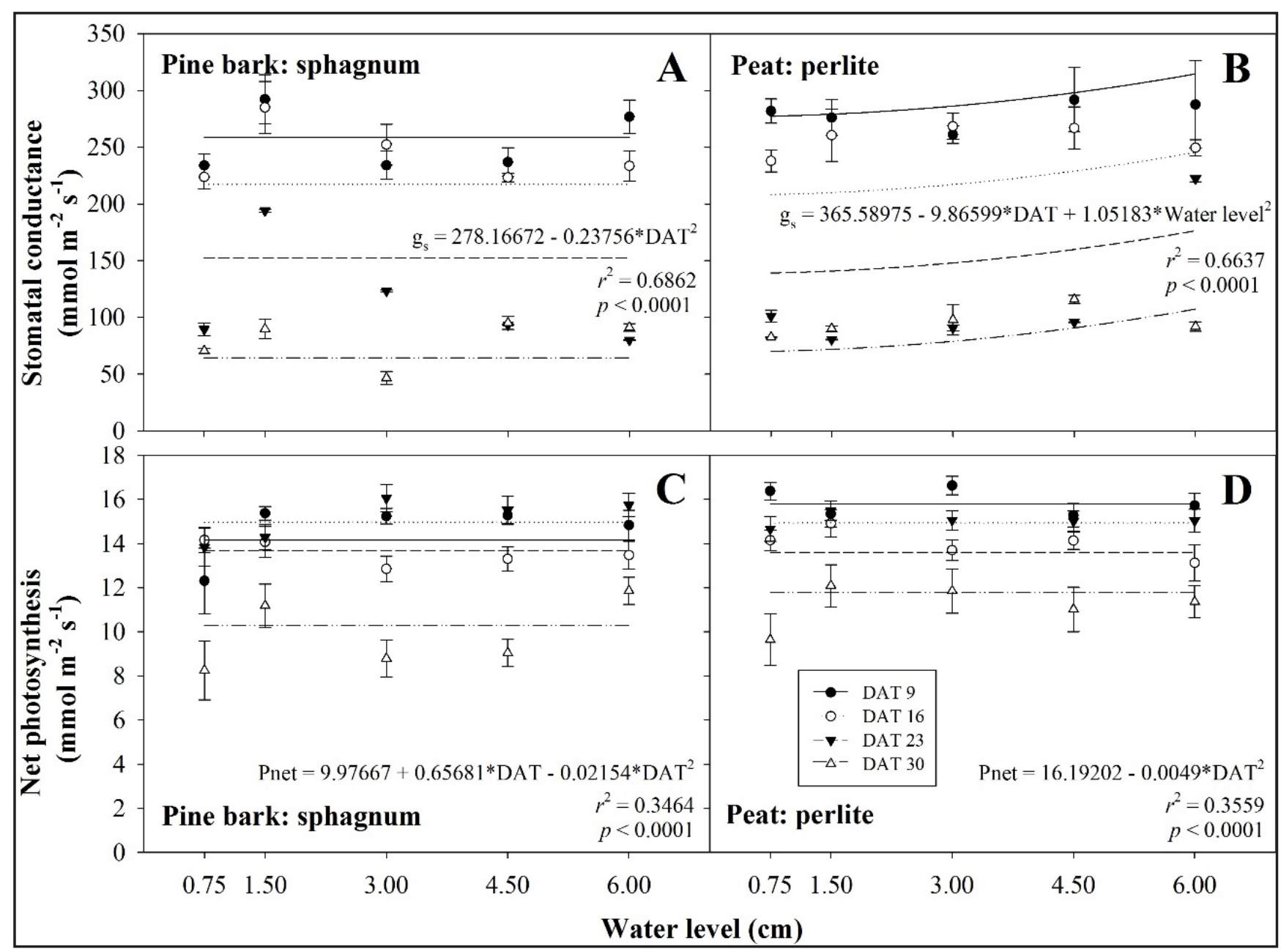

Figure 3. Stomatal conductance (A-B), and net photosynthesis (C-D) of third most fully expanded leaves of salvia 'Vista Red' grown in pine bark: sphagnum peat moss and peat: perlite substrates. Lines represent the regression equations. Each data point is the average (mean \pm standard error) of four plants per replication and four replications. DAT= days after transplanting \{condutância estomática (A-B) e fotossíntese líquida (C-D) da terceira folha totalmente expandida de sálvia 'Vista Red' cultivada em substratos de casca de pinus: esfagno e turfa: perlita. Linhas representam as equações de regressão. Cada conjunto de dados é a média (média \pm erro padrão) de quatro plantas por repetição e quatro repetições. DAT= dias após o transplantio \}. Athens, University of Georgia, 2011.

for both pine bark: sphagnum peat moss and peat: perlite at DAT 32. This trend is in agreement with Garland et al. (2012), who evaluated the influence of substrate VWC on alumroot (Heuchera americana) morphology in a sensorbased drip irrigation system. In pine bark: sphagnum peat moss, 4.5 and $6.0 \mathrm{~cm}$ of water levels resulted in a decrease in leaf area compared to the other treatments (Figure 2C), whereas in peat: perlite the leaf area decreased with the increase in water levels, indicating a negative effect of higher moisture in this peat-based substrate (Figure 2D).

The stomatal conductance decreased over time in both substrates (Figure $3 \mathrm{~A}$ and $3 \mathrm{~B}, \mathrm{p}<0.0001)$. At harvest, the lowest value occurred at $3.0 \mathrm{~cm}$ in pine bark: sphagnum peat moss, with only the plant age explaining the variation $\left(r^{2}=0.6862\right)$. The highest stomatal conductance value occurred at 4.5 $\mathrm{cm}$ in peat: perlite $\left(\mathrm{r}^{2}=0.6637\right)$. With this substrate, the partial $r$-square for DAT was 0.6430 and for water level ${ }^{2}$ just 0.0207 , indicating that water level had no meaningful effect (Table 1). Considering that lower water levels induce drought stress, the results are in agreement with Eakes et al. (1991), who determined the influence of controlled exposure of salvia 'Bonfire' plants to moisture deficit during production. Both studies consistently showed a decline in stomatal conductance over time.

Net photosynthesis also decreased over time in both substrates (Figure 3C and $3 \mathrm{D}, \mathrm{p}<0.0001)$. In both substrates, plant age explained all the responses (Figure 3C, $r^{2}=0.3464$ and Figure 3D, $\left.\mathrm{r}^{2}=0.3559\right)$ (Table 1). Eakes et al. (1991) found similar results, with reduction in net photosynthesis over time and lower results for the treatments with nonlethal dry down cycles. However, their treatments allowed the 'Bonfire' plants to reach visible wilt before rehydration, which did not happen in the current study.

Different water levels had no effect on number of branches and number of leaves at harvest (Figure 4A and $4 \mathrm{D}, \mathrm{p}>0.05)$. These results contradict Garland et al. (2012), who studied the influence of substrate water content using drip irrigation and found an 


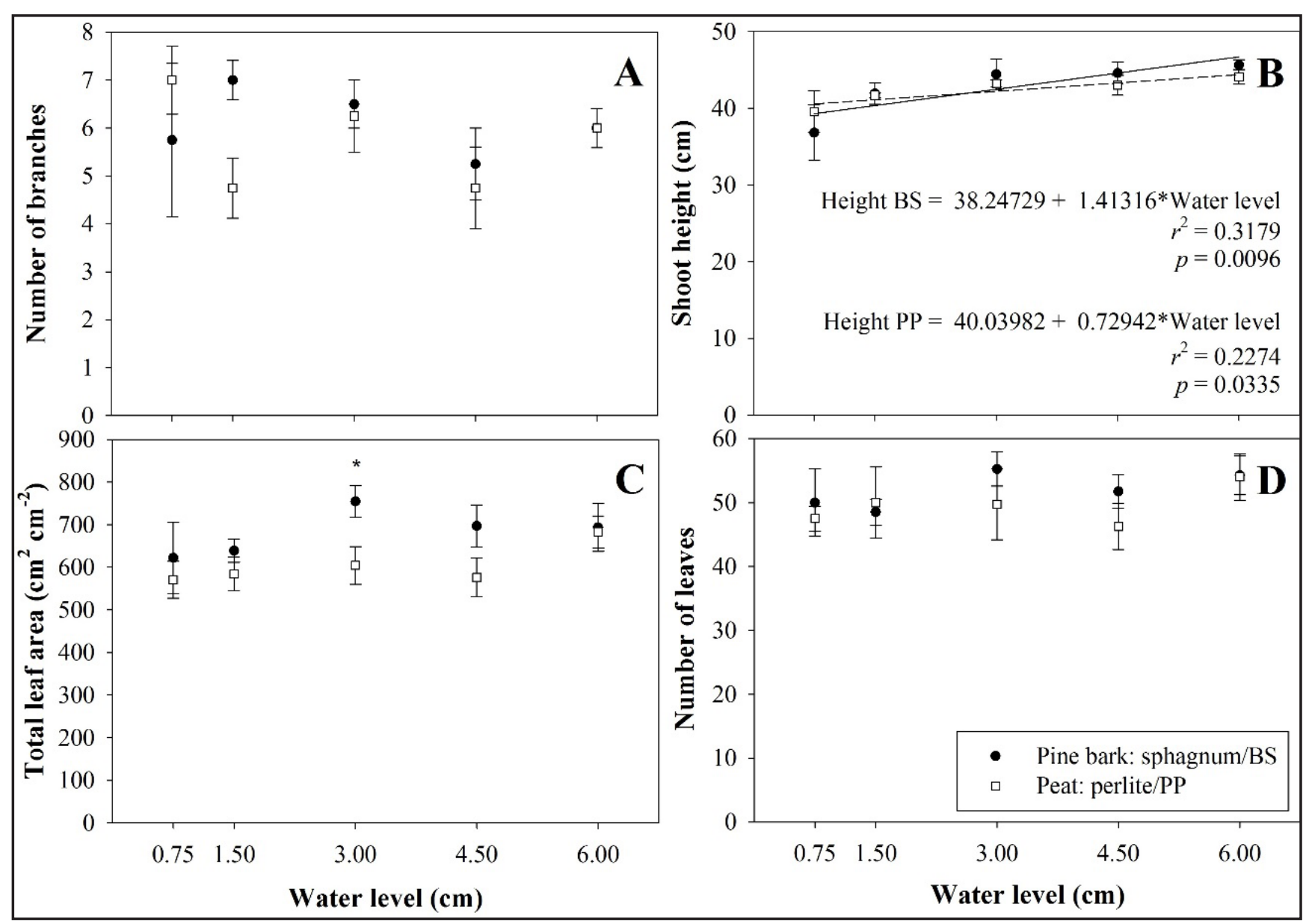

Figure 4. Number of branches (A), shoot height (B), total leaf area (C), and number of leaves (D) of salvia 'Vista Red' grown in pine bark: sphagnum peat moss (BS) and peat: perlite (PP) substrates at the end of the experiment. Lines represent the regression equations. Each data point is the average (mean \pm standard error) of four plants per replication and four replications. *significant at $5 \%$ probability \{número de ramos (A), altura da parte aérea (B), área foliar total (C), e número de folhas (D) de sálvia 'Vista Red' cultivada em substratos de casca de pinus: esfagno (BS) e turfa: perlita (PP) no final do experimento. Linhas representam as equações de regressão. Cada conjunto de dados é a média (média \pm erro padrão) de quatro plantas por repetição e quatro repetições. *significativo a 5\% de probabilidade $\}$. Athens, University of Georgia, 2011.

increase in shoot dry weight and number of leaves with increasing VWC. However, these authors tested lower VWC levels. Even though we did not have a water level effect, the total leaf area was higher in pine bark: sphagnum peat moss $\left(754.94 \mathrm{~cm}^{2}\right)$ than peat: perlite $\left(604.29 \mathrm{~cm}^{2}\right)$ at a water level of $3.0 \mathrm{~cm}$ (Figure 4C, $\mathrm{p}=0.0409$ ). Shoot height increased $13 \%$ for pine bark: sphagnum peat moss (Figure 4B, $\mathrm{p}=0.0096, \mathrm{r}^{2}=$ 0.3179 ) and $17 \%$ for peat: perlite as water level increased (Figure 4B, $\mathrm{p}=$ $0.0335, \mathrm{r}^{2}=0.2274$ ) (Table 1). This result is in agreement with Ferrarezi et al. (2015b), who showed that low VWC $\left(0.10 \mathrm{~m}^{3} / \mathrm{m}^{3}\right)$ reduced hibiscus shoot height by $30 \%$, shoot dry weight $74 \%$, and compactness by $63 \%$ compared to the $0.42 \mathrm{~m}^{3} / \mathrm{m}^{3}$ VWC threshold. These results could lead growers to use less plant growth regulators to produce better plants. Thus, financial savings can be achieved by using lower water levels. This approach will also reduce the need for tall benches, directly decreasing the size of the tanks to storage the nutrient solution, the cost of the system to support the benches, and the electrical cost to pump the solution to the system. More savings could be achieved by implementing the sensor-controlled irrigation indicated by Belayneh et al. (2013) in commercial container nurseries and greenhouses, which has allowed growers to increase their profitability by at least $21 \%$ compared to the standard practices (Lichtenberg et al., 2013). Both the total and partial dry weights (vegetative and reproductive part separately) of salvia 'Vista Red' were not different at the end of experiment (Figure 5, $p>0.05$ ), probably the result of using the same nutrient solution EC. Several authors indicated specific-responses to nutrient concentration (van Iersel, 1999; James \& van Iersel, 2001). Absence of differences on growth of Ficus benjamina 'Exotica', F. benghalensis and $F$. lyrata cultivated on ebb-and-flow benches was also described by Treder $e t$ al. (1999), who evaluated the effects of potting media (peat or peat: rockwool) and concentration of nutrient solution (EC of 1.4 and $2.1 \mathrm{dS} / \mathrm{m}$ ) on plant growth and nutrient content.

The results showed an increase in the substrate VWC in response to the increase in water levels. The hydraulic 
conductivity of the substrate played an important role in the support of water rise by capillary action, allowing the maintenance of a water column in the substrate. However, the highest water level and the higher VWC did not result in better growth performance, except shoot height. For peat: perlite, water levels $\geq 3.0 \mathrm{~cm}$ induced lower leaf chlorophyll index and stomatal conductance, with the $6.0 \mathrm{~cm}$ treatment presenting the highest shoot height. However, the VWC was over 0.55 $\mathrm{m}^{3} / \mathrm{m}^{3}$, which can result in excessive

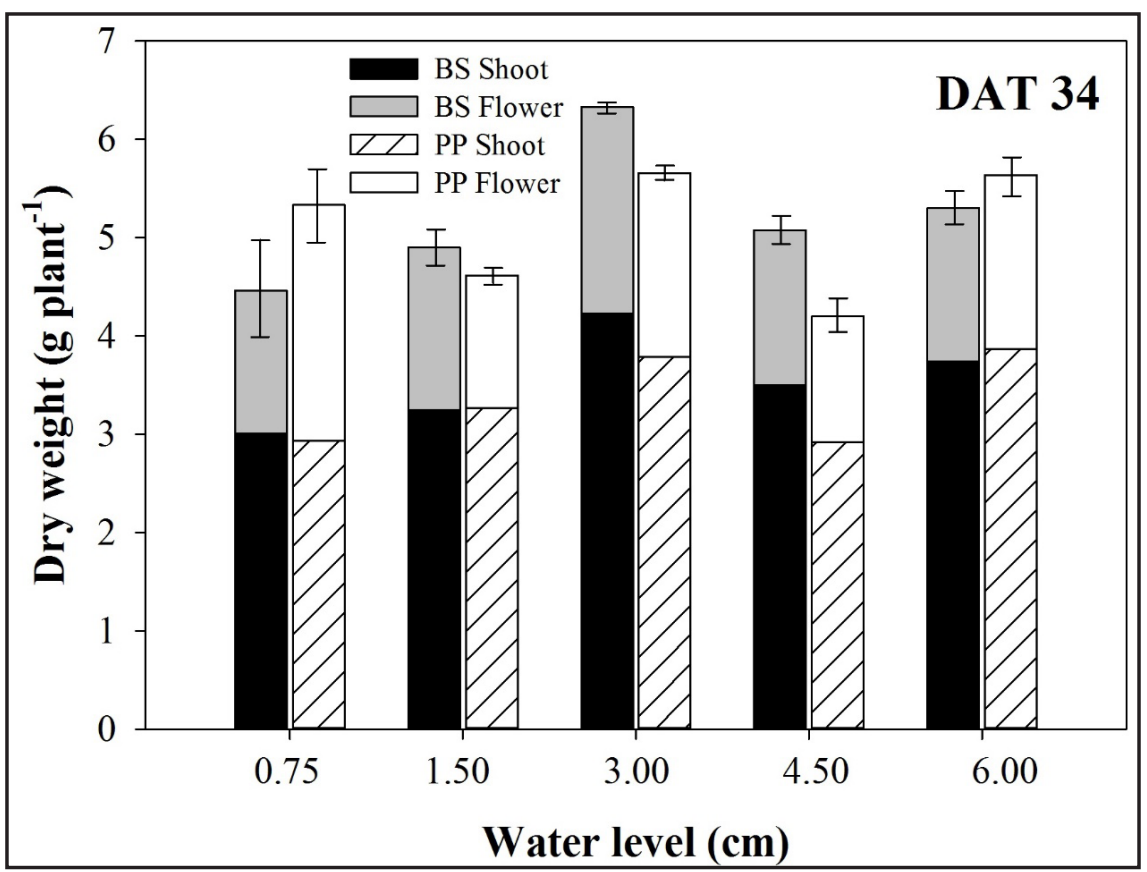

Figure 5. Total and partial (vegetative and reproductive part separately) dry weight of salvia 'Vista Red' grown in pine bark: sphagnum peat moss (BS) and peat: perlite (PP) substrates at the end of the experiment. Differences were not significant. Each bar represents the average (mean \pm standard error) of four plants per replication and four replications. DAT $=$ days after transplanting [massa seca total e parcial (parte vegetativa e reprodutiva em separado) de sálvia 'Vista Red' cultivada em substratos de casca de pinus: esfagno (BS) e turfa: perlita (PP) no final do experimento. Não houve diferenças significativas. Cada barra representa a média (média \pm erro padrão) de quatro plantas por repetição e quatro repetições. $\mathrm{DAT}=$ dias após o transplantio\}. Athens, University of Georgia, 2011. substrate moisture for some crops, being prejudicial for plant quality if not properly managed.

Higher water levels increased substrate soil moisture in subirrigation, but did not increase the total leaf area, net photosynthesis, number of branches or leaves nor plant dry weight, only the shoot plant height, what may decrease quality for salvia 'Vista Red' production. Water levels $\geq 1.5 \mathrm{~cm}$ can be recommended in subirrigation systems using pine bark: sphagnum peat moss or peat: perlite substrate without affecting crop size or quality, reducing the system cost for plant production. Further studies evaluating the combined effect of water levels and irrigation time needs to be conducted to address the main effects related to subirrigation efficiency in different growing seasons and in several other crops.

\section{ACKNOWLEDGEMENTS}

We thank the Capes Foundation (Ministry of Education, Brazil) for a scholarship to the first author as research scholar at the University of Georgia (Proc. BEX 1390/10-4) and Fafard Inc. for substrate donation. Funding for this research was provided by the American Floral Endowment and USDA-NIFASCRI award no. 2009-51181-05768. Technical help was provided by Sue K. Dove and Karina Aparecida dos Santos Soranz.

Table 1. Partial and total $r$-square analysis of leaf chlorophyll content, leaf area, stomatal conductance, net photosynthesis, and shoot height of salvia 'Vista Red' grown in pine bark: sphagnum peat moss (BS) and peat: perlite (PP) substrates based on plant age (DAT= days after transplanting) and water level (coeficientes de determinação parciais e totais do Índice de clorofila no tecido foliar, área foliar, condutância estomática, fotossíntese líquida e altura da parte aérea de sálvia 'Vista Red' cultivada em substratos de casca de pinus: esfagno (BS) e turfa: perlita (PP) com base na idade da planta (DAT= dias após o transplantio) e altura da lâmina de água\}. Athens, University of Georgia, 2011.

\begin{tabular}{|c|c|c|c|c|c|c|c|c|c|c|}
\hline & \multicolumn{2}{|c|}{$\begin{array}{l}\text { Leaf chlorophyll } \\
\text { content }\end{array}$} & \multicolumn{2}{|c|}{ Leaf area } & \multicolumn{2}{|c|}{$\begin{array}{c}\text { Stomatal } \\
\text { conductance }\end{array}$} & \multicolumn{2}{|c|}{$\begin{array}{c}\text { Net } \\
\text { photosynthesis }\end{array}$} & \multicolumn{2}{|c|}{ Shoot height } \\
\hline & BS & PP & BS & PP & BS & PP & BS & PP & BS & PP \\
\hline DAT & $0.4365 * * *$ & $0.5310 * * *$ & $0.6369 * * *$ & $0.7556^{* * *}$ & ns & $0.6430 * * *$ & $0.0725^{* *}$ & ns & ns & ns \\
\hline DAT2 & $0.1482 * * *$ & $0.1946 * * *$ & $0.0719 * * *$ & $0.0418^{* *}$ & $0.6862 * * *$ & ns & $0.2740 * * *$ & $0.3559 * * *$ & ns & ns \\
\hline Water level & $\mathrm{ns}$ & $\mathrm{ns}$ & $\mathrm{ns}$ & ns & ns & ns & ns & ns & $0.3179 * *$ & $0.2274^{*}$ \\
\hline Water level2 & ns & ns & ns & ns & ns & $0.0207 *$ & ns & ns & ns & ns \\
\hline $\begin{array}{l}\text { DAT } \times \text { water } \\
\text { level }\end{array}$ & ns & $0.0169 *$ & ns & ns & ns & ns & ns & ns & ns & ns \\
\hline Total r-square & 0.5847 & 0.7425 & 0.7088 & 0.7974 & 0.6862 & 0.6637 & 0.3465 & 0.3559 & 0.3179 & 0.2274 \\
\hline
\end{tabular}

Factors were non-significant (ns) or significant at $\mathrm{p}<0.05(*), \mathrm{p}<0.01(* *)$ or $\mathrm{p}<0.001(* * *)$ \{fatores não foram significativos (ns) ou significativos a $\mathrm{p}<0,05(*), \mathrm{p}<0,01(* *)$ ou $\mathrm{p}<0,001(* * *)\}$. 


\section{REFERENCES}

BAYER, A; MAHBUB, I; CHAPPELL, M; RUTER, J; VAN IERSEL, MW. 2013. Water use and growth of Hibiscus acetosella 'Panama Red' grown with a soil moisture sensorcontrolled irrigation system. HortScience 48: 980-987.

BELAYNEH, BE; LEA-COX, JD; LICHTENBERG, E. 2013. Costs and benefits of implementing sensor-controlled irrigation in a commercial pot-in-pot container nursery. HortTechnology 23: 760-769.

BILDERBACK, TE. 2002. Water management is key in reducing nutrient runoff from container nurseries. HortTechnology 12: 541-544.

BOGENA, H; HUISMAN, J; OBERDORSTER, C; VEREECKEN, H. 2007. Evaluation of a low-cost soil water content sensor for wireless network applications. Journal of Hydrology 344: 32-42.

CHAPPELL, M; DOVE, SK; VAN IERSEL, MW; THOMAS, PA; RUTER, J. 2013. Implementation of wireless sensor networks for irrigation control in three container nurseries. HortTechnology 23: 747-753.

EAKES, DJ; WRIGHT, RD; SEILER, JR. 1991. Moisture stress conditioning effects on Salvia splendens 'Bonfire'. Journal of the American Society for Horticultural Science 116: 716719.

FERRAREZI, RS; VAN IERSEL, MW; TESTEZLAF, R. 2014. Subirrigation automated by capacitance sensors for salvia production. Horticultura Brasileira 32: 314-320.

FERRAREZI, RS; VAN IERSEL, MW; TESTEZLAF, R. 2015b. Monitoring and controlling ebb-and-flow subirrigation with soil moisture sensors. HortScience 50: 447453.
FERRAREZI, RS; WEAVER, GM; VAN IERSEL, MW; TESTEZLAF, R. 2015a. Subirrigation: Historical overview, challenges, and future prospects. HortTechnology 25: 262-276.

FERREIRA FILHO, AC; TESTEZLAF, R; FERRAREZI，RS; RIBEIRO, MD; MARTARELLO, VD. 2012. Effect of different water levels and subirrigation times on pine bark moisture in containers. In: X CONGRESO LATINOAMERICANO Y DEL CARIBE DE INGENIERÍA AGRÍCOLA (CLIA) AND XLI CONGRESSO BRASILEIRO DE ENGENHARIA AGRÍCOLA (CONBEA). Proceedings... Cuiaba: CONBEA(CD-ROM).

GARLAND, KF; BURNETT, SE; DAY, ME; VAN IERSEL, MW. 2012. Influence of substrate water content and daily light integral on photosynthesis, water use efficiency, and morphology of Heuchera americana. Journal of the American Society of Horticultural Sciences 137: 57-67.

GENT, MPN; McAVOY, RJ. 2011. Water and nutrient uptake and use efficiency with partial saturation ebb and flow watering. HortScience 46: 791-798.

JAMES, E; VAN IERSEL, MW. 2001. Ebb and flow production of petunias and begonias as affected by fertilizers with different phosphorus content. HortScience 36: 282-285.

KIM, J; VAN IERSEL, MW; BURNETT, SE. 2011. Estimating daily water use of two petunia cultivars based on plant and environmental factor. HortScience 46: 1287-1293.

LEA-COX, JD; BAUERLE, WL; VAN IERSEL, MW; KANTOR, GF; BAUERLE, TL; LICHTENBERG, E; KING, DM; CRAWFORD, L. 2013. Advancing wireless sensor networks for irrigation management of ornamental crops: An overview. HortTechnology 23: 717-724.

LICHTENBERG, E; MAJSZTRIK, J; SAAVOSS, M. 2013. Profitability of sensor-based irrigation in greenhouse and nursery crops. HortTechnology 23: 770-774.

MIRALLES-CRESPO, J; VAN IERSEL, MW. 2011. A calibrated Time Domain Transmissometry soil moisture sensor can be used for precise automated irrigation of container-grown plants. HortScience 46: 889-894.

NEMALI, KS; MONTESANO, F; DOVE, SK; VAN IERSEL, MW. 2007. Calibration and performance of moisture sensors in soilless substrates: ECH2O and Theta probes. Scientia Horticulturae 112: 227-234.

NEMALI, KS; VAN IERSEL, MW. 2006. An automated system for controlling drought stress and irrigation in potted plants. Scientia Horticulturae 110: 292-297.

RIBEIRO, MD; FERRAREZI, RS; TESTEZLAF, R. 2014. Assessment of subirrigation performance in eucalyptus seedling production. HortTechnology 24: 231-237.

TREDER, T; MATYSIAK, B; NORWAK, JS; NOWAK, J. 1999. The effect of potting media and concentration of nutrient solution on growth and nutrient content of three Ficus species cultivated on ebb and flow benches. Acta Horticulturae 481: 433-439.

VAN IERSEL, MW. 1999. Fertilizer concentration affects growth and nutrient composition of subirrigated pansies. HortScience 34: 660-663.

VAN IERSEL, MW; CHAPPELL, M; LEA-COX, JD. 2013. Sensors for improved efficiency of irrigation in greenhouse and nursery production. HortTechnology 23: 735-746.

VAN IERSEL, MW; DOVE, SK; BURNETT, SE. 2011. The use of soil moisture probes for improved uniformity and irrigation control in greenhouses. Acta Horticulturae 893: 1049-1056.

VAN IERSEL, MW; NEMALI, KS. 2004. Drought stress can produce small but not compact marigolds. HortScience 39: 12981301. 